\title{
Korelasi Kadar Hemoglobin dengan Kadar Vascular Endothelial Growth Factor Plasma pada Tetralogi Fallot
}

\author{
Vidi Permatagalih, Sri Endah Rahayuningsih, Nanan Sekarwana \\ Departemen Ilmu Kesehatan Anak Fakultas Kedokteran Universitas Padjadjaran/Rumah Sakit Dr. Hasan \\ Sadikin, Bandung
}

\begin{abstract}
Latar belakang. Vascular endothelial growth factor-A (VEGF-A) diketahui merupakan penanda hipoksia jaringan yang berperan dalam angiogenesis. Anak dengan penyakit jantung bawaan sianotik seperti Tetralogi Fallot (TF) mengalami hipoksia jaringan dengan komplikasi timbulnya pembuluh darah baru kolateral, polisitemia hipoksik, dan anemia relatif.

Tujuan. Menentukan korelasi kadar VEGF plasma dengan kadar $\mathrm{Hb}$.

Metode. Penelitian analisis cross-sectional yang mengambil data secara konsekutif anak TF yang berobat ke poli rawat jalan dan rawat inap Departemen Ilmu Kesehatan Anak Rumah Sakit Dr. Hasan Sadikin, Bandung. Kekuatan korelasi kadar Hb dengan VEGF ditentukan dengan uji korelasi Spearman. Kemaknaan dihitung berdasarkan nilai $\mathrm{p}<0,05$. Analisis data dilakukan dengan program SPSS for windows versi 17.0.

Hasil. Duapuluh pasien anak TF yang menjadi subjek penelitian, terdiri atas 9 anak laki-laki dan 11 anak perempuan. Didapatkan korelasi negatif bermakna berkekuatan sedang antara kadar Hb dan kadar VEGF $(\mathrm{r}=-0,503 ; \mathrm{p}=0,024)$. Tidak terdapat perbedaan bermakna kadar VEGF plasma menurut jenis kelamin dan status gizi ( $\mathrm{p}=0,412$ dan 0,948 ), tetapi terdapat perbedaan bermakna kadar VEGF plasma menurut kelompok usia $(\mathrm{p}=0,048)$.

Kesimpulan. Terdapat korelasi negatif antara kadar Hb dan kadar VEGF plasma. Kadar VEGF plasma dapat diperkirakan dari kadar $\mathrm{Hb}$, apabila kadar $\mathrm{Hb}$ semakin rendah, maka kadar VEGF meningkat.
\end{abstract}

Sari Pediatri 2013;15(3):156-60.

Kata kunci: hemoglobin, tetralogi Fallot, VEGF

\footnotetext{
Alamat korespondensi:

Dr. dr. Sri Endah Rahayuningsih, Sp.A(K). M.Kes, Departemen Ilmu Kesehatan Anak Fakultas Kedokteran Universitas Padjadjaran/ RS dr. Hasan Sadikin, Jl. Pasteur 38 Bandung 40163, Telp. (022) 2035957, Fax. (022) 2034426. E-mail: endah.perkani@gmail.com
}

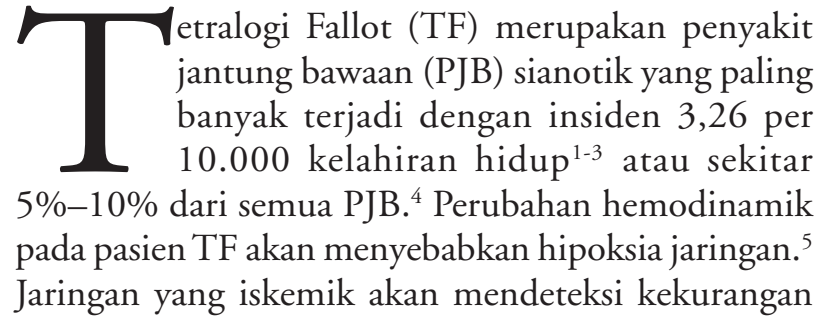


oksigen (hipoksia) atau kekurangan glukosa (hipoglikemia) serta berespons dengan menginduksi produksi faktor angiogenik secara lokal, seperti vascular endothelial growth factor (VEGF). ${ }^{6}$ Vascular endothelial growth factor- $A$ (VEGF) merupakan salah satu penanda hipoksia jaringan yang merupakan mitogen spesifik untuk sel endotel mikrovaskular dan makrovaskular dalam angiogenesis. ${ }^{7,8}$ Vascular endothelial growth factor plasma dapat dijadikan parameter untuk mengidentifikasi hipoksia jaringan. ${ }^{9}$ Pada neonatus, peningkatan kadar VEGF plasma karena hipoksia yang disebabkan oleh anemia dapat diturunkan dengan pemberian transfusi darah merah, ${ }^{9}$ sementara pada pasien TF, hipoksia yang lebih berat dapat dicegah dengan pemberian suplementasi besi yang tepat. ${ }^{4}$

Beberapa penelitian memperlihatkan bahwa pada pasien PJB sianotik terdapat peningkatan kadar VEGF plasma yang bermakna dibandingkan dengan pasien PJB nonsianotik. ${ }^{10-12}$ Peningkatan tersebut berhubungan langsung dengan konsentrasi hemoglobin $(\mathrm{Hb})$ dan berbanding terbalik terhadap keadaan hipoksia, ${ }^{10}$ tetapi penelitian terhadap 24 pasien PJB, 11 pasien PJB nonsianotik, dan 13 pasien PJB sianotik dengan diagnosis TF, memperlihatkan kadar VEGF plasma pada pasien TF lebih rendah dibandingkan dengan kadar VEGF plasma pada PJB sianotik. Dicurigai hal tersebut disebabkan kelainan gen VEGF sehingga menyebabkan terjadinya TF. ${ }^{13}$

Penelitian sebelumnya memperlihatkan korelasi positif kadar $\mathrm{Hb}$ dengan kadar VEGF plasma pada PJB sianotik, tetapi belum terdapat penelitian yang khusus meneliti hubungan kadar $\mathrm{Hb}$ dengan kadar VEGF plasma pada pasien TF anak. Pada penelitian kami, diharapkan kadar $\mathrm{Hb}$ dapat menunjukkan korelasi dengan peningkatan VEGF plasma yang pada akhirnya, dapat digunakan sebagai indikasi pemberian suplementasi besi atau transfusi darah merah pada pasien TF anak. Penanda biologi molekular VEGF untuk TF diharapkan tata laksana dan pemantauan pasien anak TF akan lebih baik lagi.

\section{Metode}

Subjek penelitian adalah anak yang didiagnosis TF, baik rawat inap maupun pasien rawat jalan di Departemen/SMF Ilmu Kesehatan Anak Rumah Sakit Dr. Hasan Sadikin, Bandung, periode April hingga Desember 2011. Kriteria inklusi, yaitu usia kurang 14 tahun, dan belum dilakukan operasi paliatif atau operasi koreksi.

Penelitian observasional analitik rancangan potong lintang, dan data dengan yang diambil secara konsekutif. Tingkat kepercayaan 95\%, power test 90\%, dan koefisien korelasi (r) 0,78 mengacu pada hasil penelitian sebelumnya, didapatkan besar sampel 20 anak. Selanjutnya dikumpulkan data berdasarkan anamnesis, pemeriksaan fisis, laboratorium, elektrokardiografi, dan ekokardiografi.

Secara statistik dilakukan analisis bivariabel untuk menentukan variabel lain yang berhubungan dengan kadar VEGF plasma, yaitu jenis kelamin, status gizi, dan usia. Selanjutnya dilakukan analisis korelasi Spearman antara kadar VEGF plasma dan kadar Hb. Analisis data menggunakan program SPSS for windows versi 17.0. Penelitian mulai dilaksanakan setelah mendapatkan persetujuan Komite Etik Penelitian Kesehatan Fakultas Kedokteran Universitas Padjadjaran RS Dr. Hasan Sadikin Bandung.

\section{Hasil}

Dari 20 pasien anak TF yang memenuhi kriteria inklusi, didapatkan 11 perempuan dan 9 laki-laki. Subjek penelitian dikelompokkan menurut rentang usia dan didapatkan kelompok usia terbanyak anak TF adalah kelompok usia 2-6 tahun (24-72 bulan). Setengah subjek penelitian mempunyai status gizi malnutrisi ringan.

Selanjutnya ditentukan perbedaaan antara jenis kelamin, status gizi, dan usia dengan kadar VEGF

Tabel 1. Karakteristik subjek penelitian

\begin{tabular}{lc}
\hline Karakteristik umum & Jumlah \\
\hline Jenis kelamin & \\
Laki-laki & 9 \\
$\quad$ Perempuan & 11 \\
Usia (tahun) & \\
$1-<2$ & 6 \\
$2-<6$ & 7 \\
$6-<12$ & 5 \\
$>12$ & 2 \\
Status gizi & \\
$\quad$ Normal & 3 \\
Malnutrisi ringan & 11 \\
Malnutrisi sedang & 6 \\
\hline
\end{tabular}


Vidi Permatagalih dkk: Korelasi kadar hemoglobin dengan kadar VEGF plasma anak TF

Tabel 2. Perbedaan jenis kelamin, status gizi, dan usia (faktor perancu) dengan kadar VEGF pasien anak TF

\begin{tabular}{|c|c|c|c|}
\hline Hubungan & Rerata (SB) & Median (rentang) & $\mathrm{p}$ \\
\hline Jenis kelamin dengan VEGF plasma & & & $\left.0,412^{*}\right)$ \\
\hline Laki-laki & $276,73(262,63)$ & $177,00(2,65-802,39)$ & \\
\hline Perempuan & $491,3(428,6)$ & $336,5(21-1.506)$ & \\
\hline Status gizi dengan VEGF plasma & & & $0,948^{* *}$ \\
\hline Normal & $130,86(82,24)$ & $132,63(47,75-212,2)$ & \\
\hline Malnutrisi ringan & $236,29(156,36)$ & $124,67(2,65-802,39)$ & \\
\hline Malnutrisi sedang & $200,59(185,70)$ & $136,91(74,27-563,66)$ & \\
\hline Usia dengan VEGF plasma (tahun) & & & $0,048^{* * *}$ \\
\hline $1-<2$ & $267,02(193,70)$ & $209,55(79,58-587,53)$ & \\
\hline $2-<6$ & $342,46(292,31)$ & $165,78(84,88-802,39)$ & \\
\hline $6-<12$ & $86,86(68,91)$ & $74,27(2,65-177,0)$ & \\
\hline$>12$ & $56,37(12,19)$ & $56,37(47,5-64,9)$ & \\
\hline
\end{tabular}

Tabel 3. Kadar VEGF plasma dan Hb serta korelasi kadar Hb dengan kadar VEGF plasma

\begin{tabular}{lllll}
\hline Variabel $(\mathrm{n}=20)$ & Rerata & SB & Median & Rentang \\
\hline Kadar VEGF $(\mathrm{pg} / \mathrm{mL})$ & 227,32 & 226,97 & 128,65 & $2,65-802,39$ \\
Kadar hemoglobin g/dL & 16,41 & 3,94 & 16,90 & $11,2-24,00$ \\
\hline
\end{tabular}

Korelasi Spearman's rank antara kadar Hb dan kadar VEGF plasma r=-0,503; $\mathrm{p}=0,024(\mathrm{p}<0,05)$

plasma (Tabel 2). Berdasarkan uji bivariabel, tidak terdapat perbedaan bermakna kadar VEGF plasma menurut jenis kelamin dan status gizi, tetapi terdapat perbedaan bermakna kadar VEGF plasma terhadap kelompok usia, yaitu kelompok usia $1-<2$ tahun dengan kelompok usia $>6$ tahun dan kelompok usia $2-<6$ tahun dengan kelompok usia $>12$ tahun. Setelah dilakukan uji korelasi Spearman, didapatkan korelasi negatif bermakna berkekuatan sedang antara kadar $\mathrm{Hb}$ dan kadar VEGF plasma anak TF (Tabel 3). Kadar Hb berkorelasi dengan kadar VEGF plasma pada pasien TF anak $(r=-0,503 ; \mathrm{p}<0,05)$, menunjukkan korelasi negatif berkekuatan sedang antara $\mathrm{Hb}$ dan kadar VEGF plasma.

\section{Pembahasan}

Dari semua pasien anak yang datang berobat ke poli rawat jalan dan dirawat di Ruang Rawat Inap Subdivisi Kardiologi Ilmu Kesehatan Anak sejak bulan April sampai dengan Desember 2011, didapatkan 32 pasien TF. Tidak semua pasien anak TF yang baru ataupun lama bersedia datang untuk dilakukan pemeriksaan darah karena berbagai alasan.
Setelah dilakukan uji statistik korelasi Spearman didapatkan korelasi negatif bermakna berkekuatan sedang antara kadar $\mathrm{Hb}$ dan kadar VEGF plasma. Hasil korelasi di atas, kadar $\mathrm{Hb}$ yang lebih rendah memperlihatkan kadar VEGF plasma yang lebih tinggi. Hal tersebut berbeda dari penelitian sebelumnya, yaitu kadar VEGF plasma berkorelasi positif sangat bermakna dengan kadar Hb. ${ }^{10,14}$

Perbandingan kadar VEGF plasma menurut usia memperlihatkan hasil yang berbeda dengan penelitian sebelumnya, yaitu kadar VEGF plasma pasien PJB sianotik usia lebih dari tiga tahun lebih tinggi dibandingkan dengan pasien yang berusia kurang dari tiga tahun. ${ }^{14}$ Penelitian Himeno, ${ }^{15}$ melaporkan pasien PJB sianotik usia di bawah tiga bulan memperlihatkan kadar VEGF plasma yang lebih tinggi dibandingkan dengan kadar VEGF plasma pada usia di atas tiga bulan. Pada penelitian tersebut, kadar VEGF plasma usia setelah tiga bulan tidak berubah dengan bertambah usia dan pada pasien PJB sianotik tetap memperlihatkan kadar VEGF plasma yang lebih tinggi dibandingkan dengan PJB nonsianotik. ${ }^{15}$ Pada pasien TF dengan stenosis pulmonal, derajat hipoksia akan meningkat seiring dengan keparahan stenosis pulmonal yang akan bertambah berat dengan bertambahnya usia. ${ }^{1,4}$ 
Hal tersebut pada penelitian sebelumnya ditandai pula dengan peningkatan kadar VEGF plasma. ${ }^{14}$ Pada penelitian kami tidak demikian karena kelompok usia lebih besar secara statistik memperlihatkan kadar VEGF plasma yang lebih rendah. Kemungkinan karena pada bayi baru lahir hingga beberapa bulan setelah lahir kadar VEGF plasma meningkat seiring banyaknya pertumbuhan pembuluh darah dan pembuluh darah paru. ${ }^{16}$

Kondisi lain penyebab kadar VEGF plasma lebih tinggi pada usia lebih muda karena kerusakan molekul VEGF, atau reseptor penyebab defek ekspresi VEGF terhadap hipoksia, sehingga tidak terjadi peningkatan kadar VEGF plasma pada usia yang lebih besar sejalan dengan bertambahnya derajat stenosis pulmonal. Vascular endothelial growth factor merupakan faktor endotelial yang penting untuk pertumbuhan dan pembentukan pembuluh darah baru, dan pembentukan katup jantung. Ekspresi VEGF yang rendah karena berbagai faktor dapat menyebabkan kelainan perkembangan jantung dan katup-katupnya. ${ }^{17}$ Penelitian sebelumnya terhadap tikus memberikan hasil yang mendukung bahwa mutasi atau kelainan pada gen VEGF dapat berkontribusi terjadinya TF pada tikus. ${ }^{18}$ Pada tahun 2005, Lambercht $\mathrm{dkk}^{19}$ melakukan penelitian terhadap pasien TF yang juga memperlihatkan hasil bahwa ekspresi VEGF plasma yang rendah dapat meningkatkan risiko terjadinya TF. Pada tahun 2009, penelitian pasien TF menunjukkan tidak terdapat hubungan antara VEGF dan terjadinya TF. $^{20}$ Penelitian terbaru terhadap 24 pasien PJB, 11 pasien PJB nonsianotik, dan 13 pasien PJB sianotik, yaitu dengan diagnosis TF memperlihatkan kadar VEGF plasma pada pasien TF lebih rendah dibandingkan dengan kadar VEGF plasma pada PJB sianotik dengan kecurigaan terjadi kelainan pada reseptor VEGF atau pada VEGF itu sendiri sehingga ekpresi VEGF rendah. ${ }^{13}$

Pada pasien TF, anemia dapat dialami apabila rangsangan hipoksia kronik terhadap sumsum tulang melalui ginjal menyebabkan peningkatan jumlah eritrosit, dan tanpa disertai asupan besi yang memadai dapat memperberat kondisi hipoksia. ${ }^{21}$ Kondisi tersebut sangat berhubungan dengan usia dan tingkat keparahan stenosis pulmonal. ${ }^{1-3,21}$ Pada penelitian kami, kemungkinan derajat hipoksia yang terjadi pada usia lebih muda belum berat sehingga belum terjadi polisitemia, seperti pada bayi yang belum memperlihatkan gejala sianosis berat atau karena terjadi anemia yang bukan disebabkan defisiensi besi.

Hasil akhir yang didapatkan pada penelitian kami adalah makin rendah kadar $\mathrm{Hb}$, maka makin tinggi kadar VEGF plasma pada anak TF. Pasien dengan PJB sianotik pada beberapa penelitian sebelumnya memperlihatkan korelasi positif antara kadar VEGF plasma dan kadar $\mathrm{Hb}$, dengan pemikiran adanya keadaan hipoksia kronik dapat menyebabkan polisitemia dengan kadar $\mathrm{Hb}$ yang meningkat yang menjadi stimulus kuat angiogenesis. ${ }^{14,15}$ Perbedaan penelitian kami dengan penelitian lain sangat mungkin karena populasi yang berbeda; karena pada beberapa penelitian sebelumnya subjek adalah semua PJB sianotik, sementara pada penelitian kami hanya pasien TF. Keterbatasan penelitian kami, antara lain jumlah kasus yang kurang dan mempunyai rentang usia yang sangat besar.

\section{Kesimpulan}

Disimpulkan bahwa terdapat korelasi negatif antara $\mathrm{Hb}$ dan kadar VEGF plasma. Kadar VEGF plasma pada pasien TF dapat ditaksir dari kadar Hb. Dokter anak sebagai klinisi dapat memperkirakan kondisi hipoksia yang terjadi pada anak TF dengan melihat kadar $\mathrm{Hb}$. Diperlukan penelitian lebih lanjut secara prospektif dengan jumlah sampel yang lebih besar untuk menentukan cut-offpoint $\mathrm{Hb}$ dalam inisiasi pemberian preparat besi atau transfusi. Penelitian lebih lanjut juga diperlukan untuk meneliti mengenai kontribusi VEGF terhadap terjadinya TF dengan analisis genetik gen VEGF pada pasien TF.

\section{Daftar pustaka}

1. Breitbart RE, Flyer DC. Tetralogy of fallot. Dalam: Keane JF, Lock JE, Flyer DC, penyunting. Nadas' pediatric cardiology. Edisi ke-2. Philadelphia: Elsevier-Saunders; 2006.h.559-80.

2. Bailliard F, Anderson RH. Review: tetralogy of fallot. Orphanet J Rare Dis. 2009 [diunduh 12 September 2010]. Didapat dari: BioMed Central. http://www.ojrd. $\mathrm{com} /$

3. Apitz C, Anderson RH, Redington AN. Tetralogy of fallot with pulmonary stenosis. Dalam: Anderson RH, Baker EJ, Penny D, Redington AN, Rigby ML, Wernovsky G, penyunting. Pediatric cardiology. Edisi ke-3. 
Philadelphia: Elsevier; 2010.h.753-73.

4. Park MK. Pediatric cardiology for practitioners. Edisi ke-5. Philadelphia: Mosby Elsevier; 2008.

5. Webb GD, Smallhorn JF, Therrien J, Redington AN. Disease of the heart, pericardium, and pulmonary vasculature bed. Dalam: Libby P, Bonow RO, Mann DL, Zipes DP, penyunting. Braunwald's heart disease; a textbook of cardiovascular medicine. Edisi ke-8. Philadelphia: Elsevier; 2008.h.1561-624.

6. Dor Y, Porat R, Keshet E. Vascular endothelial growth factor and vascular adjustments to pertubations in oxygen homeostasis. Am J Physiol Cell Physiol 2001;280:136774.

7. Ferrara N, Smyth TD. The biology of vascular endothelial growth factor. Endocrine Rev 1997;18:4-25.

8. Ferrara N. Vascular endothelial growth factor: basic science and clinical progress. Endocrine Rev 2004;25: 581-611.

9. Tschirch E, Weber B, Koehne P, Guthman F, Gise AV, Wauer RR, dkk. Vascular endothelial growth factor as a marker for tissue hypoxia and transfusion need in anemic infant: a prospective clinical study. Pediatrics 2009; 123:784-90.

10. Baghdady YMK, Mohamed S. Vascular endothelial growth factor in children with cyanotic and acyanotic congenital heart disease. Heart Mirror J 2008;2:24-7.

11. Ootaki Y, Yamaguchi M, Yoshimura N, Oka S, Yoshida $M$, Hasegawa T. Vascular endothelial growth factor in children with congenital heart disease. Ann Thorac Surg 2003;75:1523-6.

12. Suda K, Matsumura M, Miyanish S, Uehara K, Sugita T, Matsumoto M. Increased vascular endothelial growth factor in patients with cyanotic congenital heart disease may not be normalized after Fontan type operation. Ann Thorac Surg 2004;78:942-6.

13. Tolunay I, Tunauglu S, Akyurek N, Halid V, Olgunturk R, Kula S. Serum and pulmonary vascular endothelial growth factor/receptors and haemodynamic measure- ments in cyanotic congenital heart disease with decreased pulmonary blood flow. Cardiol Young 2011;21:608-15.

14. Melegy NTE, Mohamed NA. Angiogenic biomarkers in children with congenital heart disease: possible implications. Italian J Pediatr 2010;36:32.

15. Himeno W. Angiogenic growth factors in patients with cyanotic congenital heart disease and in normal children. Kurume Med J 2001;48:111-6.

16. Lassus P, Ristimaki AT, Ylikorlala O, Anderson S. Vascular endothelial growth factor in human preterm lung. Am Respir Cret Care Med 1999;159:1429-33.

17. Amstrong FJ, Bischoff J. Heart valve development: endothelial signaling and differentiation. Circ Res 2004;95:459-70.

18. Akker NMS, Molin DGM, Peters PPWM, Maas S, Wisse LJ, Brempt R, dkk. Tetralogy of fallot and alteration in vascular endothelial growth factor-A signaling and notch signaling in mouse embryo solely expressing the VEGF120 isoform. Circulation Research 2007;100:842-9.

19. Lambrecths D, Devriendt K, Driscoll DA, Goldmuntz E, Gewilig M, Vlietinck R, dkk. Low expression VEGF haplotype increase the risk for tetralogy of fallot: a family based association study. J Med Genet 2005;42:519-22.

20. Griffin HR, Hall DH, Topf A, Eden J, Stuart G, Parson J,, dkk. Genetic variation in VEGF does not contribute significantly to the risk of congenital cardiovascular malformation. Plos One J 2009;4:e4978.

21. Andrews NC. Iron deficiency and related disorders. Dalam: Lee GR, Bithell TC, Foerster J, Athens JW, Lukens JN, penyunting. Wintrobe's clinical hematology. Edisi ke-11. Philadelphia: Lippincott Williams \& Wilkins; 2004.h.969-1009.

22. Siwik ES, Erenberg F, Zahka KG, Goldmuntz E. Tetralogy of fallot. Dalam: Allen HD, Driscoll DJ, Shaddy RE, Feltes TS, penyunting. Moss and adams' heart disease in infant, children and adolescent, including fetus and younf adult. Edisi ke-7. Volume 2. Philadelphia: Lippincott Williams \& Wilkins; 2007.h.889-910. 